\title{
PHYTOPLANKTON DIVERSITY AND STOICHIOMETRIC NUTRIENT LIMITATION IN THE LAGOS HARBOUR AND ADJACENT SEA, SOUTHWESTERN NIGERIA
}

\author{
Elegbeleye, O. W." and Onyema, I. C. \\ Department of Marine Sciences, University of Lagos, Nigeria. \\ *Corresponding author's email: owelegbeleye@gmail.com; Tel.: (+234)8025253343 \\ (Received: $24^{\text {th }}$ May, 2019; Accepted: $29^{\text {th }}$ September, 2019)
}

\section{ABSTRACT}

\begin{abstract}
Harbours and their adjacent seas are increasingly stressed by maritime activities and development of coastal cities worldwide. This is especially true for the Lagos Harbour. The aim of this study was to investigate the trophic status, nutrient stoichiometry and phytoplankton assemblage of Lagos Harbour and the adjacent sea. Water and plankton samples were collected for a period of eighteen months from January 2015 to June 2016 between 06.00 and 11.00 hrs each time. Phytoplankton samples were investigated using a Leica DMLB microscope with 100x full oil immersion optics and 1.35 numerical aperture equipped with a Nikon Coolpix 995 CCD digital camera of 3.3 megapixel resolution. Relevant statistical tests such as Principal Components Analysis (PCA) were employed to determine major controlling water quality indices and Canonical Correspondence Analysis (CCA) for determination of the water quality indices that influenced the monthly and spatial phytoplankton occurrences. A total of 108 phytoplankton taxa belonging to five classes were recorded in this study. Bacillariophyceae comprised eighty-four (84) taxa (78\%), Chlorophyceae had two (2) taxa $(2 \%)$, Cyanophyceae were represented by 11 taxa (10\%), Dictyochophyceae had one (1) taxon (1\%) and Dinophyceae had 10 taxa $(9 \%)$. CCA revealed a clear seasonal pattern; it also showed that phosphate was the major controlling factor in the Lower Lagos Harbour and the creeks in the months of July, August and September 2015. Trophic state index (TSI) using Carlson's indices revealed eutrophic to hypereutrophic conditions. The comparison of ambient nutrient ratios with Redfield ratio $(\mathrm{N}: \mathrm{P}=16: 1)$ revealed clear spatial and temporal variations in the Lagos Harbour and adjacent sea. The significant difference shown by phosphate in the wet season could be linked to allochthonous and autochthonous inputs from rainfall.
\end{abstract}

Keywords: Harbour, Microscopy, Nutrient stoichiometry, Phytoplankton.

\section{INTRODUCTION}

The aquatic ecosystems are a precious resource, essential to humanity, and also to the function of our planet (Castro and Huber, 2005). The biodiversity, high productivity and ecosystem services provided by tropical coastal systems are noteworthy (Onyema, 2009). However, increasing population and utilization/exploitation of resources have subjected coastal ecosystems to many environmental challenges from humaninduced impacts. Notably, harbours and their adjacent seas are increasingly stressed by maritime activities and development of coastal cities worldwide.

The Lagos Harbour is no exception in these regards, as worthy of note is the indiscriminate dredging and sand mining activities in the Lagos lagoon. There has also been an unprecedented land reclamation in this coastal water for the ongoing development of the Eko Atlantic City. The effects of these anthropogenic activities could negatively impact the water quality indices and thereby interfere with the natural composition of aquatic bio-forms. Phytoplankton are sensitive bio-indicators of ecosystem general health, its nutrient status, eutrophication, pollutants and other anthropogenic impacts in aquatic environments (Barbosa et al., 2010).

In particular, these organisms respond rapidly to wide range of pollutants and thus, can provide potentially useful early warning signals of deteriorating conditions and the possible causes (Graham et al., 2009). The occurrences and density of different types of species of phytoplankton in the bodies of water are usually affected by water quality. The fundamental indicators of water quality are its physical (total dissolved solids, total suspended solids and water temperature) and chemical (chemical oxygen demand, dissolved oxygen, nutrients, $\mathrm{pH}$ and salinity) properties which are usually affected by the inputs entering into the aquatic ecosystem 
(Falkowski et al., 2008). This study aims at investigating phytoplankton species diversity and determine the factors influencing their abundance and distribution in the Lagos Harbour.

\section{MATERIALS AND METHODS}

\section{Study Area}

Lagos lagoon is an open tidal estuarine ecosystem situated within the low-lying coastal zone of Nigeria. It is located at the eastern part of the Lagos lagoon complex. It lies parallel to Epe lagoon and extends from part of Lekki lagoon. It falls within the rain forest belt characterized by a well-marked wet (May - October) and dry (November - April) seasons (Nwankwo, 2004a; Onyema, 2009; Chukwu, 2011; Edokpayi, 2017). The Lagos Harbour, which is part of the Lagos lagoon, is the only direct opening for the nine marginal Southwestern lagoons to the sea in Nigeria. To the West of the harbour are Yewa,
Ologe Badagry, and Iyagbe lagoons. And to the east of the Lagos Harbour are the Kuramo, Lagos, Epe, Lekki and Mahin lagoons. Before now, coastal erosion was a major environmental menace at the Victoria beach in the Lagos Harbour. However, in 2013, Lagos State Government succeeded in building high-wave resistant groins (Great Wall of Lagos) at the Victoria beach to address this environmental challenge and at the same time, reclaim land in this aquatic ecosystem to allow for the construction of a new city, the Eko Atlantic City.

\section{Sampling Stations}

Twelve stations in three ecologically distinct zones (the horizontal gradient of the harbour channel, adjoining creeks and the open sea adjacent to the harbour) were selected (Table 1 and Figure 1). There are four stations each within these three ecological zones. 
Table 1: Sampling Stations, Corresponding Global Positioning System (GPS) Coordinates and Average Secchi Depths

\begin{tabular}{|c|c|c|c|c|}
\hline $\mathrm{S} / \mathrm{N}$ & Stations & GPS coordinates & $\begin{array}{l}\text { Average } \\
\text { Secchi depth } \\
\text { (meters) }\end{array}$ & $\begin{array}{l}\text { Descriptions of locations and notes on } \\
\text { anthropogenic activities/ecological } \\
\text { interests }\end{array}$ \\
\hline 1 & $\begin{array}{l}\text { Lower Lagos } \\
\text { Harbour (LH) }\end{array}$ & $\begin{array}{l}6.4655455^{\circ} \mathrm{N}, \\
3.3817855^{\circ} \mathrm{E}\end{array}$ & 1.10 & $\begin{array}{l}\text { Former sewage disposal site; fishing } \\
\text { activities; receives wood shavings from } \\
\text { Okobaba sawmill. }\end{array}$ \\
\hline 2 & $\begin{array}{l}\text { Upper Lagos } \\
\text { Harbour (UH) }\end{array}$ & $\begin{array}{l}6.4418984^{\circ} \mathrm{N} \\
3.4047894^{\circ} \mathrm{E}\end{array}$ & 2.10 & Fishing activities; Jetty; boat cruises \\
\hline 3 & Takwa bay (TB) & $\begin{array}{l}6.3998240^{\circ} \mathrm{N}, \\
3.3965815^{\circ} \mathrm{E}\end{array}$ & 2.40 & $\begin{array}{l}\text { Fishing activities; recreational } \\
\text { activities; boat cruises; ongoing } \\
\text { construction of Eko Atlantic City }\end{array}$ \\
\hline 4 & $\begin{array}{l}\text { Commodore } \\
\text { Channel (CC) }\end{array}$ & $\begin{array}{l}6.3916082^{\circ} \mathrm{N} \\
3.4007852^{\circ} \mathrm{E}\end{array}$ & 2.50 & $\begin{array}{l}\text { Mouth of the harbour to the sea; } \\
\text { vessels' passage; Fishing activities; } \\
\text { ongoing construction of Eko Atlantic } \\
\text { City }\end{array}$ \\
\hline 5 & Ijora Creek (IC) & $\begin{array}{l}6.4626541^{\circ} \mathrm{N} \\
3.3765639^{\circ} \mathrm{E}\end{array}$ & 0.20 & $\begin{array}{l}\text { Naval dockyard; local settlements; } \\
\text { fishing activities; riparian mangroves }\end{array}$ \\
\hline 6 & $\begin{array}{l}\text { Badagry Creek } \\
\text { (BC) }\end{array}$ & $\begin{array}{l}6.4332895^{\circ} \mathrm{N} \\
3.3697329^{\circ} \mathrm{E}\end{array}$ & 1.50 & $\begin{array}{l}\text { Tincan Island Port; Folawiyo Energy } \\
\text { Tank; Human settlements; Fishing } \\
\text { activities; riparian mangroves }\end{array}$ \\
\hline 7 & $\begin{array}{l}\text { Lighthouse Creek } \\
\text { (LHC) }\end{array}$ & $\begin{array}{l}6.4237596^{\circ} \mathrm{N}, \\
3.3915698^{\circ} \mathrm{E}\end{array}$ & 0.50 & $\begin{array}{l}\text { Lagos Deep Offshore Logistics } \\
\text { (LADOL) office site; dredging and } \\
\text { sand mining activities }\end{array}$ \\
\hline 8 & $\begin{array}{l}\text { Five-cowrie } \\
\text { Creek (FC) }\end{array}$ & $\begin{array}{l}6.4398202^{\circ} \mathrm{N}, \\
3.4015017^{\circ} \mathrm{E}\end{array}$ & 1.10 & $\begin{array}{l}\text { Fastest flowing creek in Southwestern } \\
\text { Nigeria; Fishing activities; dredging } \\
\text { and sand mining at the Moba end of } \\
\text { the creek; boat cruises }\end{array}$ \\
\hline 9 & $\begin{array}{l}\text { Lighthouse Beach } \\
1 \text { (LHB1) }\end{array}$ & $\begin{array}{l}6.3894741^{\circ} \mathrm{N} \\
3.3961648^{\circ} \mathrm{E}\end{array}$ & 2.70 & Fishing activities; recreation \\
\hline 10 & $\begin{array}{l}\text { Lighthouse Beach } \\
2 \text { (LHB2) }\end{array}$ & $\begin{array}{l}6.3909665^{\circ} \mathrm{N} \\
3.3938614^{\circ} \mathrm{E}\end{array}$ & 2.80 & Vessels' anchorage; fishing activities \\
\hline 11 & $\begin{array}{l}\text { Great wall of } \\
\text { Lagos } 1 \text { (GW1) }\end{array}$ & $\begin{array}{l}6.389474^{\circ} \mathrm{N} \\
3.396165^{\circ} \mathrm{E}\end{array}$ & 2.80 & $\begin{array}{l}\text { Ongoing construction of Eko Atlantic } \\
\text { City; fishing activities }\end{array}$ \\
\hline 12 & $\begin{array}{l}\text { Great wall of } \\
\text { Lagos } 2(G W 2)\end{array}$ & $\begin{array}{l}6.4004850^{\circ} \mathrm{N} \\
3.4257971^{\circ} \mathrm{E}\end{array}$ & 3.10 & $\begin{array}{l}\text { Vessels' anchorage; fishing activities; } \\
\text { fishing activities }\end{array}$ \\
\hline
\end{tabular}




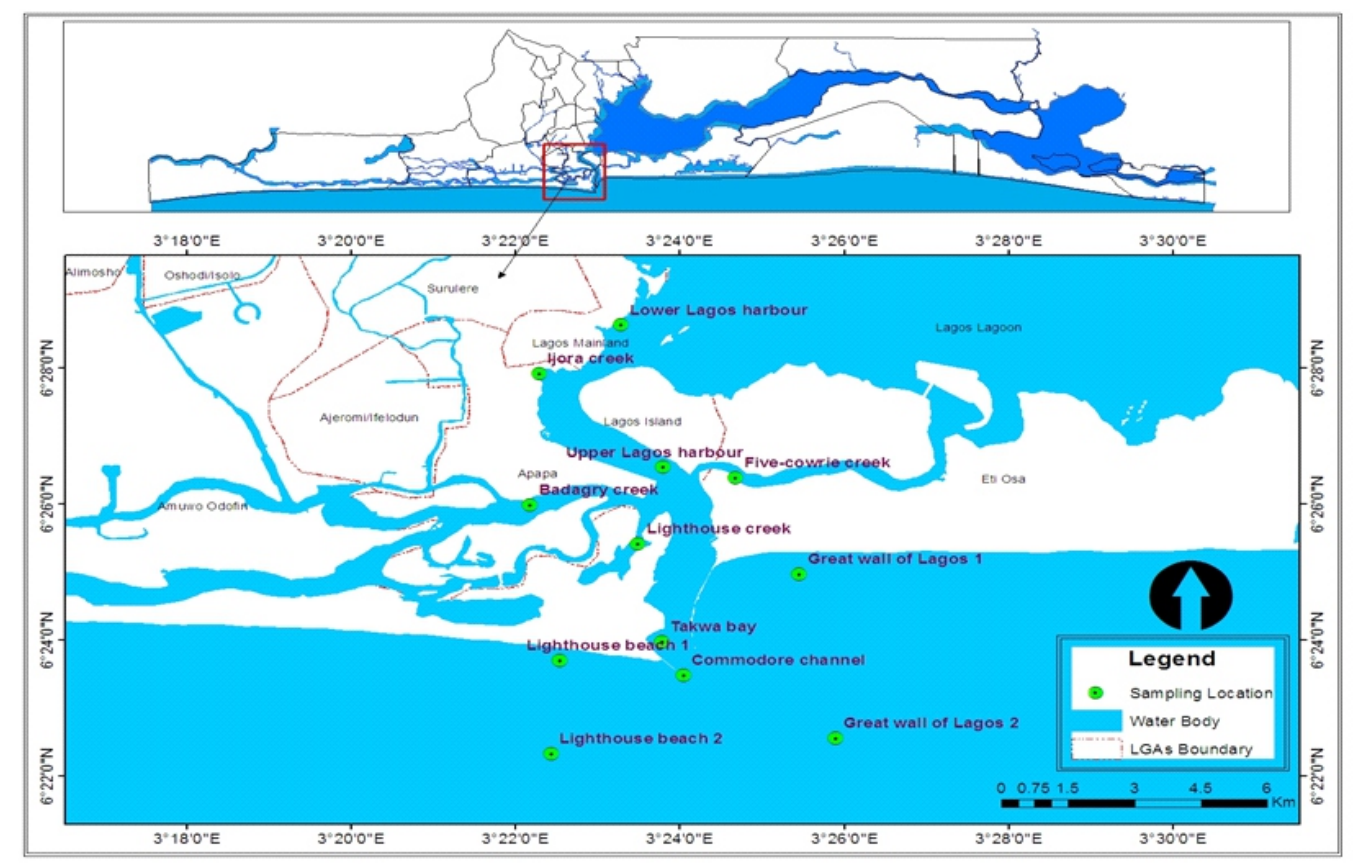

Figure 1: The Lagos Harbour and Adjacent Sea showing Study Sites

\section{Collection of Samples Water Samples}

Monthly sampling was conducted and water samples were collected for a period of eighteen months from January 2015 to June 2016 between 06.00 and 11.00 hours each day. Replicate samples were collected at every site on each occasion for the analyses of nutrients and all other water quality parameters. Integrated surface water samples were collected between $0-1 \mathrm{~m}$ depth. Samples for dissolved oxygen were fixed in-situ with Winkler's reagents (APHA, 2005).

\section{Plankton Samples}

Samples were collected using standard plankton net of mesh size $55 \mu \mathrm{m}$. The plankton net was towed horizontally from a motorized boat at low speed ( $<4$ knots) for 5 minutes and the filtered plankton were emptied into well-labelled plastic container with a screw-cap. The plankton samples were preserved with $4 \%$ formalin and transferred to the laboratory for further analysis as described by Nwankwo (2004b) and Julius and Theriot (2010).

\section{Microscopic Analysis of Phytoplankton}

In the laboratory, fixed phytoplankton samples were allowed to settle and concentrated to $50 \mathrm{ml}$. The samples were investigated using a Leica
DMLB microscope with 100x full oil immersion optics and 1.35 numerical aperture equipped with a Nikon Coolpix 995 CCD digital camera (3.3 megapixel resolution). Phytoplankton abundance was estimated in cells/filaments/trichomes per liter of seawater using a modified enumeration method described by Perry (2003). Confirmation of species identification were done using relevant texts (Nwankwo, 2004b; Al-kandari et al., 2009; Alvarez-Blanco and Blanco, 2014).

\section{Statistical Analyses}

Relevant statistical tests such as one-way Analysis of Variance (ANOVA) to determine the levels of variations in water quality parameters across stations; Principal Components Analysis (PCA) to determine major controlling water quality indices; Bray-Curtis Analysis of Similarities (ANOSIM) to determine cohorts in study sites; Canonical Correspondence Analysis (CCA) and Pearson's correlation coefficient for determination of the water quality indices that influenced the monthly and spatial phytoplankton occurrences were employed. All statistical analyses were done using Excel, Paleontological Statistics (PAST) (Hammer et al., 2001) and Statistical Package for Social Sciences (SPSS). 


\section{Trophic Status Evaluation}

The Trophic State Index (TSI) developed by Carlson (1977) was adopted for this study. Mean values of three variables - chlorophyll $a$ (chl a), phosphate (TP) and Secchi depth (SD) were used to calculate TSI within a numerical trophic continuum. The formulae for calculating TSI values for chlorophyll a, reactive phosphorus and Secchi depth are stated below.

TSI chlorophyll a $=9.811 \mathrm{n}(\mathrm{chl})+30.6$;

TSI reactive phosphorus $=14.421 \mathrm{n}(\mathrm{TP})+4.15$; TSI Secchi depth $=60-14.411 \mathrm{n}(\mathrm{SD})$.

Therefore;

$$
\text { Carlson'sTSI }=\frac{T S I(C h l a)+T S I(T P)+T S I(S D)}{3}
$$

\section{Stoichiometric Nutrient Limitation}

The Redfield Nitrate: Phosphate ratio of 16:1 was used as a benchmark for differentiating Nitratelimitation from Phosphate-limitation. This ratio assumes that phytoplankton is Nitrate-limited (Nlimited) at $\mathrm{N}: \mathrm{P}<16$ and that it is Phosphatelimited (P-limited) at N:P $>16$.

\section{RESULTS \\ Physicochemical Properties of Surface Waters}

The mean variations and analysis of variance (ANOVA) of physicochemical parameters of the surface water in the Lagos Harbour and adjacent sea during wet and dry seasons of the sampling period are presented in table 2. Data are presented as means \pm standard error (SE). The peak of rainfall $(449.3 \mathrm{~mm})$ was recorded in June, 2015. Whereas salinity, Total Dissolved Solids, Dissolved Oxygen were found to be higher in the dry season, Biochemical Oxygen Demand and phosphate recorded higher values in the wet season than in dry season.

Principal Component Analysis (PCA) depicted that clusters were determined based on similar controlling factors. PCA grouped the twelve sampling stations into two clusters (Figure 2). Cluster 1 (LH - Lower Lagos Harbour, BC Badagry Creek, LHC - Lighthouse Creek, IC Ijora Creek, FC -Five-cowrie Creek, UH - Upper Lagos Harbour) and Cluster 2 (TB - Takwa Bay, CC - Commodore Channel, LHB1 - Lighthouse Beach 1, LHB2 - Lighthouse Beach 2, GW1 Great Wall of Lagos 1 and GW2 - Great Wall of Lagos 2). The PCA explained $98.73 \%$ for component $1,1.24 \%$ for component 2 and $0.03 \%$ for component 3 of the total variation of the studied ecosystems, while the Eigen values are 5.67E $+07,713442$ and 15745.8 for components 1 , 2 and 3 respectively. Total Dissolved Solids (TDS), Biochemical Oxygen Demand (BOD) and Chemical Oxygen Demand (COD) were controlling factors in stations grouped as Cluster 1 whereas stations grouped as Cluster 2 were majorly influenced by salinity, nitrate, Total Suspended Solids (TSS), phosphate, Dissolved Oxygen, conductivity and air temperature. 
Elegbeleye" and Onyema: Phytoplankton Diversity and Stoichiometric Nutrient Limitation

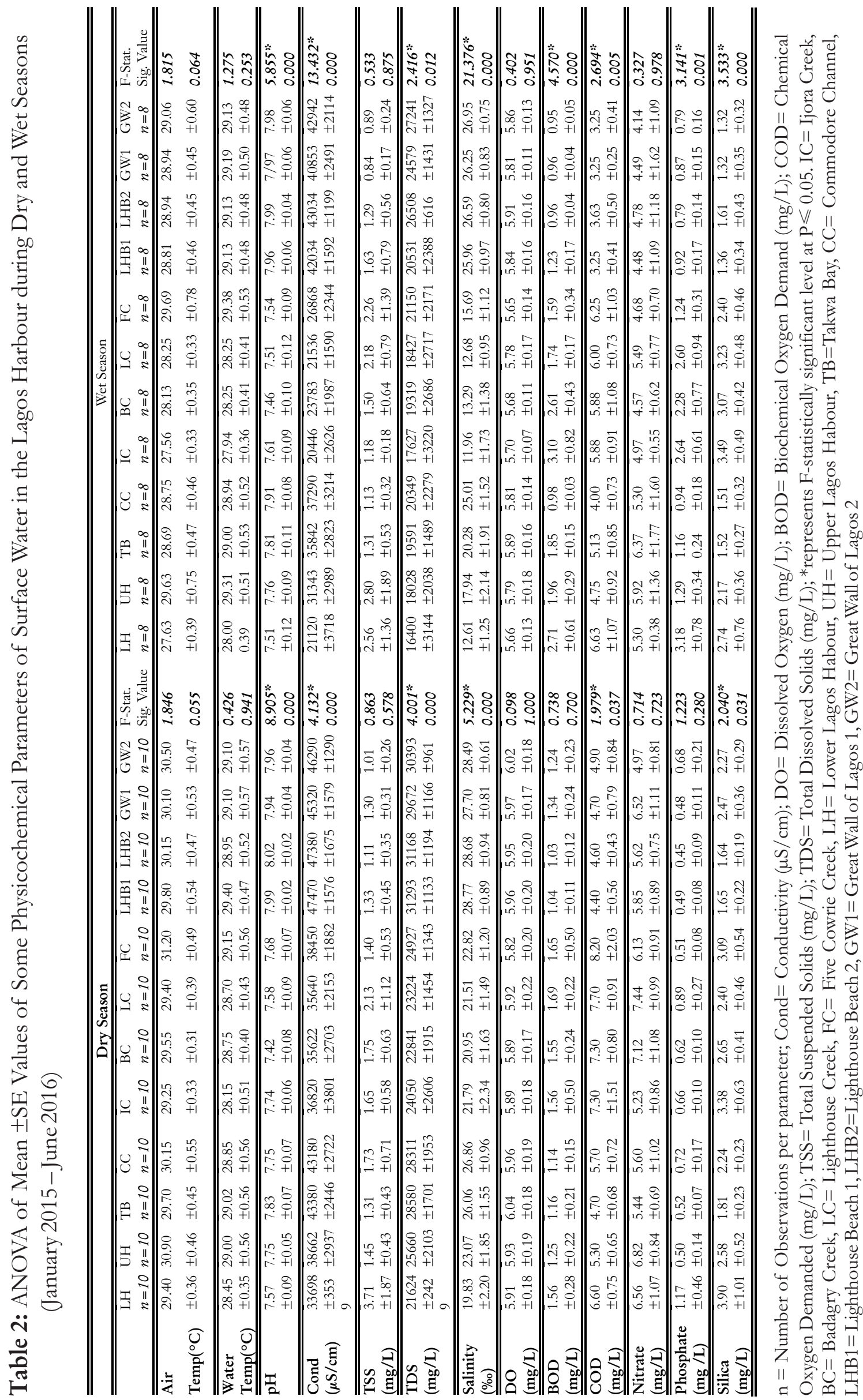




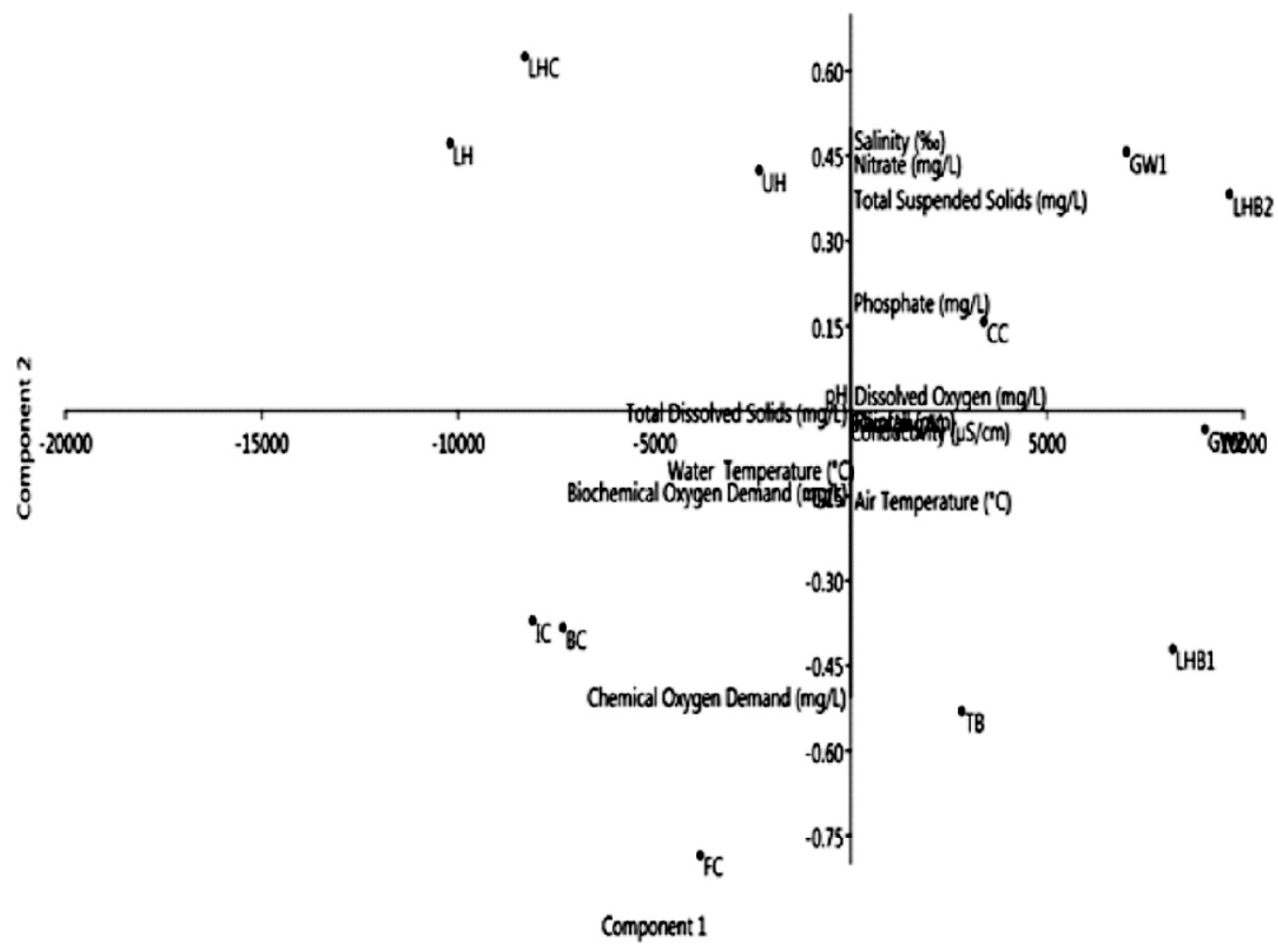

Figure 2: PCA Score Plot of Physicochemical Parameters Operating in the Lagos Harbour and Adjacent Sea, Southwest, Nigeria

LH - Lower Lagos Harbour, UH - Upper Lagos Harbour, TB - Takwa Bay, CC - Commodore Channel, IC - Ijora Creek, BC - Badagry Creek, LHC - Lighthouse Creek, FC - Five-cowry Creek, LHB1 - Lighthouse Beach 1, LHB2 - Lighthouse Beach 2, GW1 - Great Wall of Lagos 1, GW2 - Great Wall of Lagos 2

Phytoplankton Species Diversity andwet seasons respectively. In the wet season, the Abundance Lighthouse beach 2 (in the sea) was found to be A total of 108 phytoplankton taxa belonging to five classes were recorded in this study. Bacillariophyceae (diatoms) comprised eightyfour (84) taxa (78\%), Chlorophyceae (green algae) had two (2) taxa (2\%), Cyanophyceae (blue-green algae) were represented by 11 taxa $(10 \%)$, Dictyochophyceae (silicoflagellates) had one (1) taxon (1\%) and Dinophyceae (dinoflagellates) had $10 \operatorname{taxa}(9 \%)$.

Generally, diatoms were found to be the most abundant group across seasons for all stations (Figures 3 and 4). However, in the wet season, Ijora, Badagry, Lighthouse and Five-cowrie creeks recorded higher numerical abundance of cyanobacteria compared to other phytoplankton group. In terms of numerical abundance, Badagry creek recorded the highest number of species. Tables 3 and 4 are the diversity indices for dry and the most diverse in terms of species.

However, the creeks had the most diverse composition of phytoplankton species in the dry season. At taxon level, of ecological concern was the bloom (30,000-45,000 trichomes per $\mathrm{ml}$ ) of a blue-green alga, Oscillatoria tenuis in the wet months of July, August and September, 2015 at Ijora, Badagry, Lighthouse and Five-cowrie creeks. The bloom was observed in August and September, 2015 at Lower Lagos Harbour. These blooms were responsible for the higher phytoplankton abundance recorded in the months of July, August and September, 2015 (Figure 5).

\section{Analysis of Similarities (ANOSIM) Based on Phytoplankton}

Bray-Curtis analysis of similarity grouped the twelve sampling stations into three statistically 
significant clusters using phytoplankton Lighthouse Beach 1, GW1 - Great Wall of Lagos composition as a basis (Figure 6). Cluster 1 (LHB2 1) and cluster 3 (IC - Ijora Creek, BC - Badagry - Lighthouse Beach 2, GW2 - Great Wall of Lagos Creek, LHC - Lighthouse Creek, FC - Five-cowry 2), cluster 2 (UH - Upper Lagos Harbour, TB - creek and LH - Lower Lagos Harbour).

Takwa Bay, CC - Commodore Channel, LHB1 -
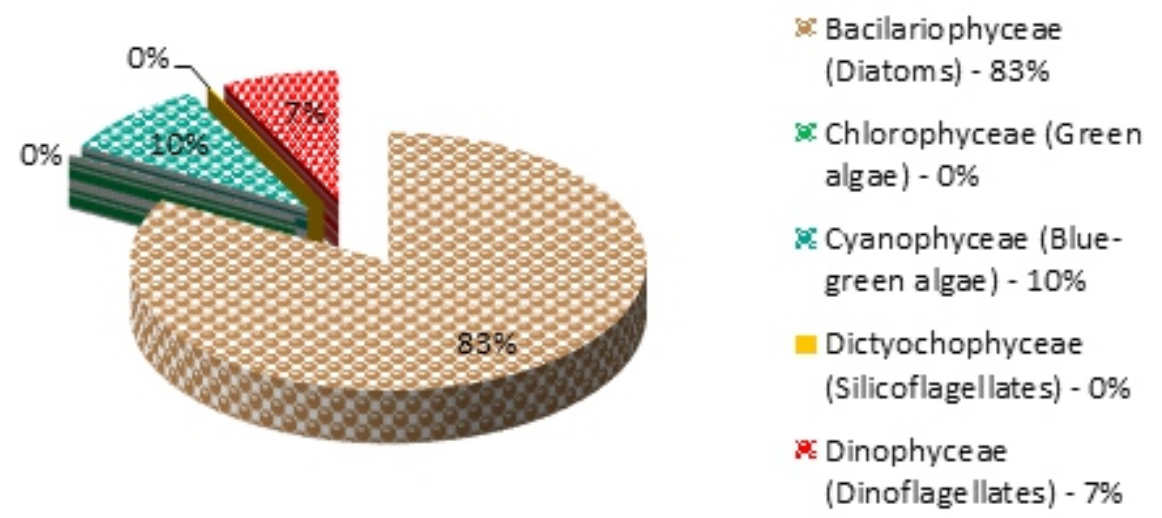

Figure 3: Percentage Composition of Phytoplankton in the Lagos Harbour and Adjacent Sea During the Dry Season (January 2015 - June 2016)
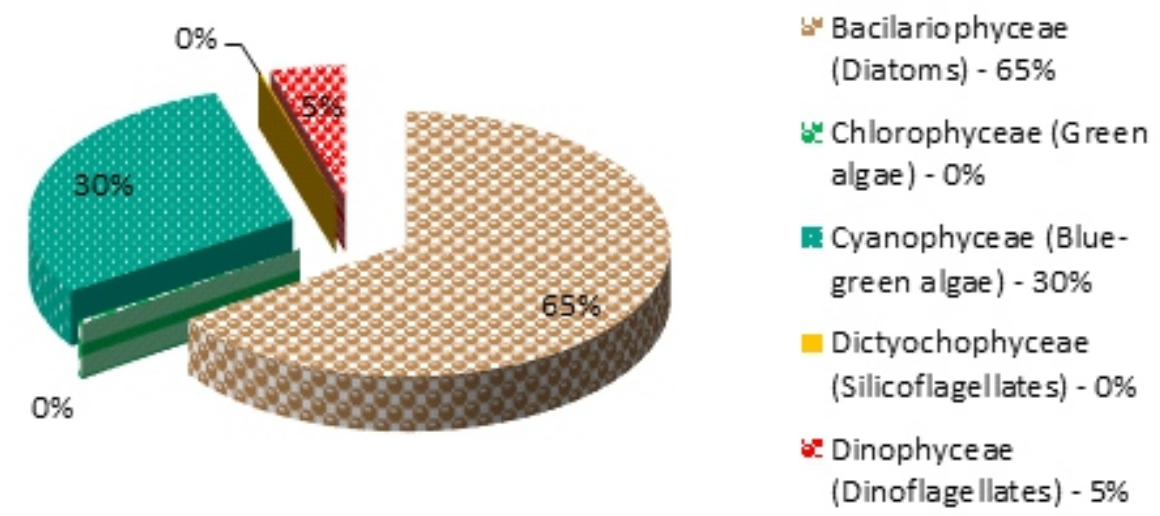

Figure 4: $\quad$ Percentage Composition of Phytoplankton in the Lagos Harbour and Adjacent Sea in the Wet Season (January 2015 - June 2016)

Table 3: Algal Diversity Indices at Sampled Sites in the Lagos Harbour and Adjacent Sea During Dry Season (January 2015-June 2016)

\begin{tabular}{|c|c|c|c|c|c|c|c|c|c|c|c|c|}
\hline & LH & $\overline{\mathrm{UH}}$ & TB & $\mathrm{CC}$ & IC & $\mathrm{BC}$ & LHC & FC & LHB1 & LHB2 & GW1 & GW2 \\
\hline Taxa_S & 106 & 104 & 104 & 104 & 106 & 106 & 106 & 106 & 104 & 100 & 104 & 101 \\
\hline Simpson_1-D & 0.9806 & 0.9735 & 0.9761 & 0.9761 & 0.9812 & 0.983 & 0.9825 & 0.983 & 0.9711 & 0.9866 & 0.9724 & 0.9867 \\
\hline Shannon_H & 4.222 & 4.078 & 4.146 & 4.145 & 4.237 & 4.306 & 4.289 & 4.309 & 4.038 & 4.428 & 4.106 & 4.43 \\
\hline Evenness_e^H/S & 0.6434 & 0.5678 & 0.6077 & 0.6072 & 0.6527 & 0.6995 & 0.6876 & 0.7015 & 0.5453 & 0.838 & 0.5839 & 0.8313 \\
\hline Menhinick & 0.7933 & 0.5704 & 0.5928 & 0.5929 & 0.8079 & 0.7402 & 0.7425 & 0.7448 & 0.5913 & 0.974 & 0.6607 & 0.9924 \\
\hline Margalef & 10.73 & 9.893 & 9.967 & 9.967 & 10.77 & 10.58 & 10.58 & 10.59 & 9.962 & 10.69 & 10.18 & 10.82 \\
\hline Equitability_J & 0.9054 & 0.8781 & 0.8928 & 0.8926 & 0.9085 & 0.9234 & 0.9197 & 0.924 & 0.8694 & 0.9616 & 0.8841 & 0.96 \\
\hline
\end{tabular}


Elegbeleye" and Onyema: Phytoplankton Diversity and Stoichiometric Nutrient Limitation

Table 4: Algal Diversity Indices at Sampled Sites in the Lagos Harbour and Adjacent Sea During Wet Season (January, 2015 - June, 2016)

\begin{tabular}{lllllllllllll}
\hline & LH & UH & TB & CC & IC & BC & LHC & FC & LHB1 & LHB2 & GW1 & GW2 \\
\hline Taxa_S & 79 & 100 & 100 & 100 & 79 & 89 & 88 & 87 & 99 & $\mathbf{1 0 2}$ & 100 & 101 \\
Simpson_1-D & 0.8667 & 0.9688 & 0.9713 & 0.9714 & 0.7632 & 0.8439 & 0.8411 & 0.8273 & 0.9643 & $\mathbf{0 . 9 8 5}$ & 0.9606 & 0.9847 \\
Shannon_H & 3.042 & 3.858 & 3.919 & 3.92 & 2.614 & 3.061 & 3.048 & 2.965 & 3.77 & $\mathbf{4 . 3 7 6}$ & 3.776 & 4.362 \\
Evenness_e`H/S & 0.2652 & 0.4735 & 0.5036 & 0.5042 & 0.1727 & 0.2398 & 0.2394 & 0.223 & 0.4381 & $\mathbf{0 . 7 7 9 8}$ & 0.4363 & 0.7763 \\
Menhinick & 0.518 & 0.5259 & 0.5444 & 0.5441 & 0.4307 & 0.4464 & 0.4435 & 0.4483 & 0.5466 & $\mathbf{1 . 1 0 4}$ & 0.6603 & 1.092 \\
Margalef & 7.758 & 9.433 & 9.495 & 9.494 & 7.483 & 8.309 & 8.222 & 8.162 & 9.425 & $\mathbf{1 1 . 1 6}$ & 9.86 & 11.04 \\
Equitability_J & 0.6963 & 0.8377 & 0.8511 & 0.8513 & 0.5981 & 0.6819 & 0.6807 & 0.664 & 0.8204 & $\mathbf{0 . 9 4 6 2}$ & 0.8199 & 0.9451 \\
\hline
\end{tabular}

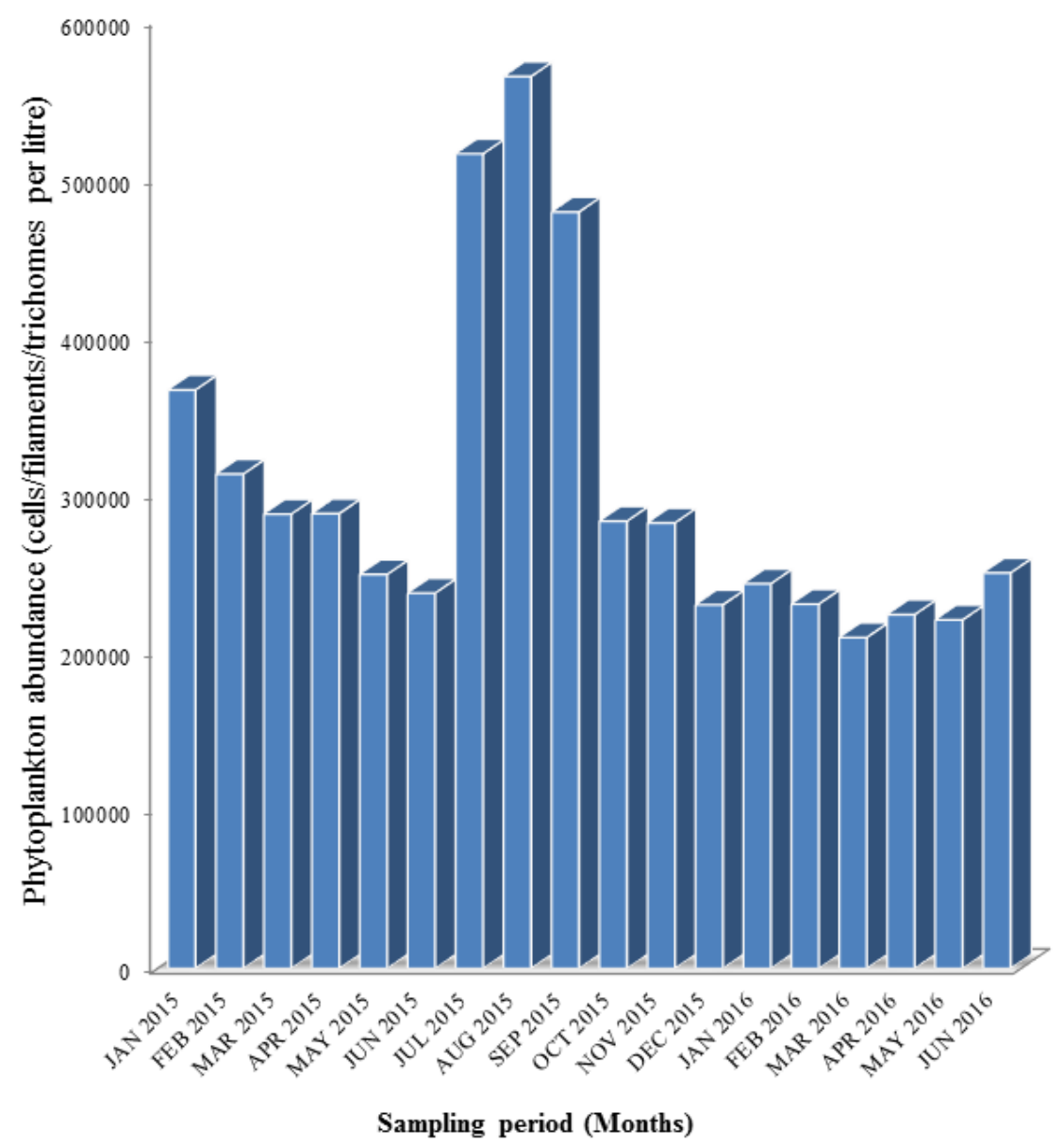

Figure 5: Monthly Variations in Phytoplankton Abundance in the Lagos Harbour and Adjacent Sea, Southwest, Nigeria (January 2015 - June 2016) 


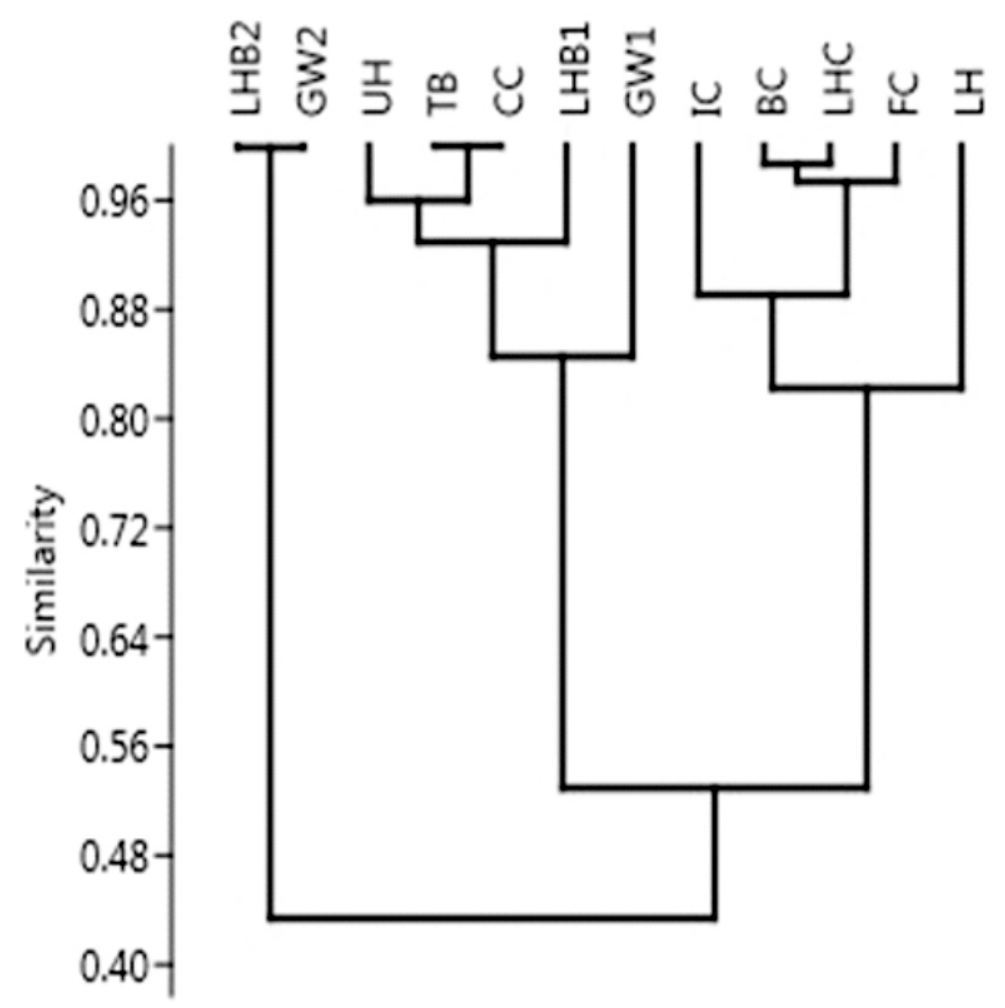

Figure 6: Bray-Curtis Analysis of Similarity in Phytoplankton Composition of the Lagos Harbour and Adjacent Sea, Southwest, Nigeria (January 2015 - June 2016)

$\mathrm{LH}=$ Lower Lagos Habour, UH= Upper Lagos Habour, TB= Takwa Bay, CC $=$ Commodore Channel, $\mathrm{IC}=$ Ijora Creek, $\mathrm{BC}=$ Badagry Creek, LHC $=$ Lighthouse Creek, FC $=$ Five Cowrie Creek, LHB1 $=$ Lighthouse Beach 1, LHB2= Lighthouse Beach 2, GW1 = Great Wall of Lagos 1, GW2=Great Wall of Lagos 2

\section{Effects of Water Physicochemical Parameters on Phytoplankton}

In order to identify the major factors which influenced phytoplankton distribution and abundance at study sites, various statistical tools were applied. Canonical Correspondence Analysis revealed a clear seasonal pattern; it also showed that phosphate was the major controlling factor in the Lower Lagos Harbour (LH), Ijora (IC), Badagry (BC), Lighthouse (LHC) and Five-cowrie (FC) creeks in the months of July, August and September, 2015 (Figure 7).
The results from Pearson's product coefficient between nutrients and abundance of phytoplankton are presented in table 5. There existed significant positive correlations between phosphate and the abundances of blue-green (Cyanophyceae) and green algae (Chlorophyceae); on the other hand, amount of phosphate had significant negative impact on dinoflagellates (Dinophyceae) and silicoflagellates (Dictyochophyceae). Silica had significant positive relationship with green algae; also, its effect on silicoflagellates was profoundly positive. 
Elegbeleye" and Onyema: Phytoplankton Diversity and Stoichiometric Nutrient Limitation

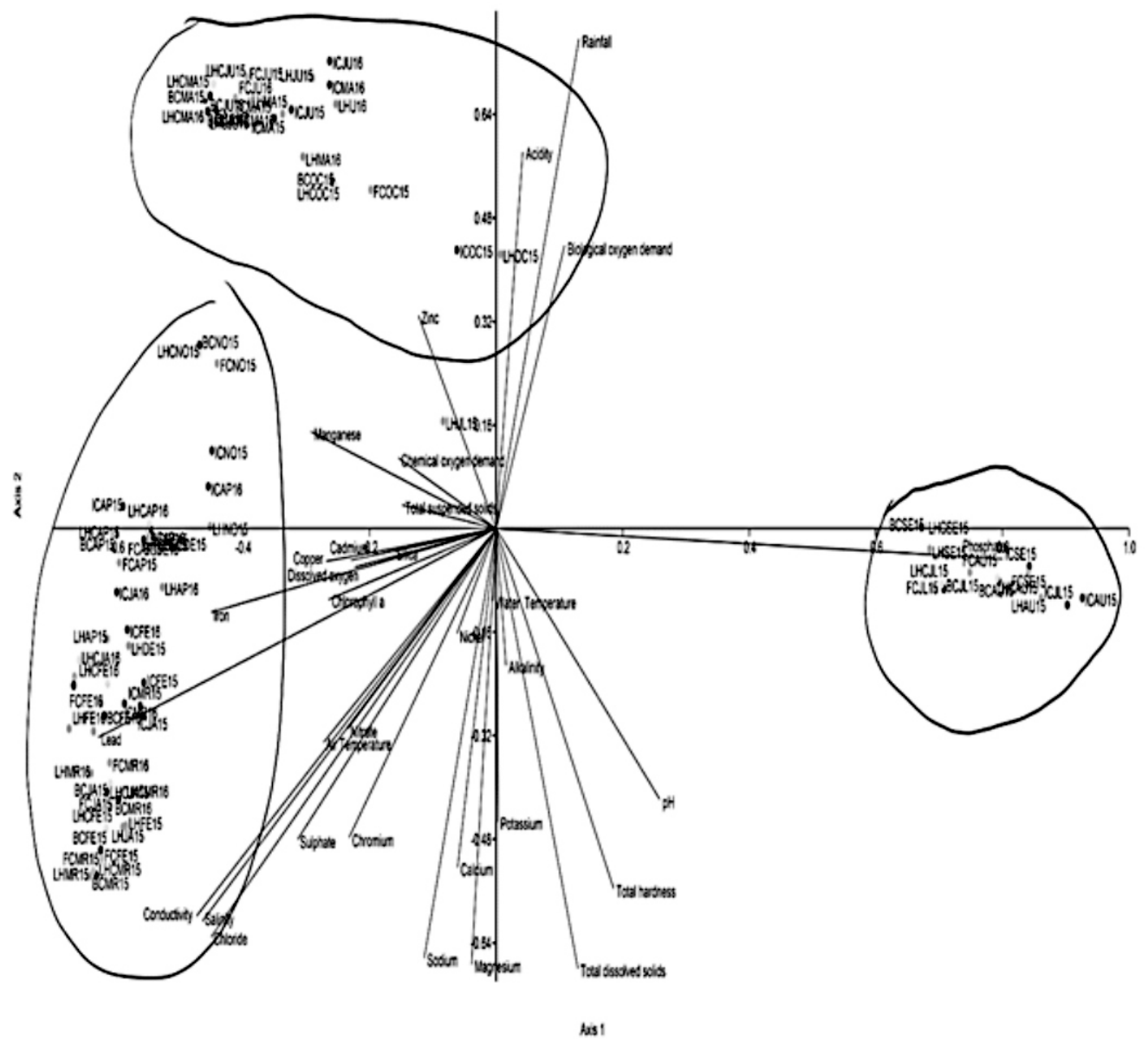

Figure 7: Canonical Correspondence Analysis of physico-chemical parameters in the Lower Lagos Harbour and the creeks adjoining the Harbour (January 2015- June 2016)

NB: The first two letters connote the name of station, next two letters indicate the month and the last two digits represent the year of sampling. Example: ICAU15 means Ijora Creek in August 2015 
Table 5: Relationship (as a measure of effect) between some Nutrients (Nitrate, Phosphate, Silica, and Sulphate) and Abundance of Phytoplankton Taxonomic Groups

\begin{tabular}{|c|c|c|c|c|c|c|c|c|c|}
\hline & $\begin{array}{l}\text { Nitrate } \\
n=216\end{array}$ & $\begin{array}{l}\text { Phosphate } \\
n=216\end{array}$ & $\begin{array}{l}\text { Silica } \\
\mathrm{n}=216\end{array}$ & $\begin{array}{l}\text { Sulphate } \\
\mathrm{n}=216\end{array}$ & $\begin{array}{l}\text { Bacillariop } \\
\text { hyceae } \\
n=216\end{array}$ & $\begin{array}{l}\text { Chloro } \\
\text { phyceae } \\
n=216\end{array}$ & $\begin{array}{l}\text { Cyano } \\
\text { phyceae } \\
n=216\end{array}$ & $\begin{array}{l}\text { Dictycho } \\
\text { phyceae } \\
n=216\end{array}$ & $\begin{array}{l}\text { Dino } \\
\text { phyceae } \\
n=216\end{array}$ \\
\hline Nitrate & $\begin{array}{l}5.64^{\mathrm{m}} \\
\left(3.04^{\mathrm{s}}\right)\end{array}$ & & & & $\begin{array}{l}-0.044^{\mathrm{r}} \\
(0.517 \mathrm{p})\end{array}$ & $\begin{array}{l}-0.102^{\mathrm{r}} \\
(0.137 \mathrm{p})\end{array}$ & $\begin{array}{l}-0.08^{\mathrm{r}} \\
(0.244 \mathrm{P})\end{array}$ & $\begin{array}{l}0.011^{\mathrm{r}} \\
(0.875 \mathrm{p})\end{array}$ & $\begin{array}{l}0.051^{\mathrm{r}} \\
(0.457 \mathrm{p})\end{array}$ \\
\hline Phosphate & & $\begin{array}{l}1.05^{\mathrm{m}} \\
\left(1.21^{\mathrm{s}}\right)\end{array}$ & & & $\begin{array}{l}0.089^{\mathrm{r}} \\
(0.190 \mathrm{p})\end{array}$ & $\begin{array}{l}0.653^{\mathrm{r} *} \\
\left(0.000^{\mathrm{p}}\right)\end{array}$ & $\begin{array}{l}0.756^{\mathrm{r} *} \\
\left(0.000^{\mathrm{p}}\right)\end{array}$ & $\begin{array}{l}-0.196^{r *} \\
\left(0.004^{p}\right)\end{array}$ & $\begin{array}{l}-0.231^{\mathrm{r} *} \\
\left(0.001^{\mathrm{p}}\right)\end{array}$ \\
\hline Silica & & & $\begin{array}{l}2.35^{\mathrm{m}} \\
\left(1.52^{\mathrm{s}}\right)\end{array}$ & & $\begin{array}{l}-0.048^{\mathrm{r}} \\
(0.486 \mathrm{P})\end{array}$ & $\begin{array}{l}0.195^{\mathrm{r} *} \\
\left(0.004^{\mathrm{p}}\right)\end{array}$ & $\begin{array}{l}0.081^{\mathrm{r}} \\
(0.235 \mathrm{p})\end{array}$ & $\begin{array}{l}-0.189^{r *} \\
\left(0.005^{p}\right)\end{array}$ & $\begin{array}{l}-0.077^{\mathrm{r}} \\
(0.258 \mathrm{p})\end{array}$ \\
\hline Sulphate & & & & $\begin{array}{l}1729.24^{\mathrm{m}} \\
\left(483.66^{\mathrm{s}}\right)\end{array}$ & $\begin{array}{l}0.071^{\mathrm{r}} \\
\left(0.302^{\mathrm{p}}\right)\end{array}$ & $\begin{array}{l}-0.416^{\mathrm{r} *} \\
\left(0.000^{\mathrm{p}}\right)\end{array}$ & $\begin{array}{l}-0.344^{\mathrm{r} *} \\
(0.000 \mathrm{p})\end{array}$ & $\begin{array}{l}-0.161^{\mathrm{r} *} \\
\left(0.018^{\mathrm{p}}\right)\end{array}$ & $\begin{array}{l}-0.186^{r *} \\
\left(0.006^{p}\right)\end{array}$ \\
\hline Bacillariophyceae & & & & & $18812^{\mathrm{m}}$ & & & & \\
\hline Chlorophyceae & & & & & & $61^{\mathrm{m}}$ & & & \\
\hline Cyanophyceae & & & & & & & $4951^{\mathrm{m}}$ & & \\
\hline Dictychophyceae & & & & & & & & $37 \mathrm{~m}$ & \\
\hline Dinophyceae & & & & & & & & & $1490^{\mathrm{m}}$ \\
\hline
\end{tabular}

The mean of each variable with their respective standard deviation is on the diagonal of the table with superscripts $\mathrm{m}$ and $\mathrm{s}$. The calculated $\mathrm{r}$ values with respective $\mathrm{p}$-values are above the diagonals, $\mathrm{n}=$ number of observations.

\section{Trophic State Index}

Trophic state index (TSI) using Carlson's indices revealed eutrophic to hypereutrophic conditions. Whereas stations such as Takwa Bay (TB), Commodore Channel (CC), Lighthouse Beach 1 and 2 (LHB1 and LHB2), Great Wall of Lagos 1 and 2 (GW1 and GW2) were found to be within the lower boundary of classical eutrophy (TSI = 50 - 60), Lower Lagos Harbour (LH), Badagry (BC), Lighthouse (LC) and Five-cowrie creeks (FC) were observed to be hypereutrophic (TSI = $70-80)$. On the other hand, Ijora creek was found to be extremely hypereutrophic with TSI of 83 . Figure 8 shows the profile of trophic states for sampled stations in the Lagos Harbour and adjacent sea.

\section{Stoichiometric Nutrient Limitation}

The comparison of ambient nutrient ratios with Redfield ratio (N:P = 16:1) revealed clear spatial and temporal variations in the Lagos Harbour and adjacent sea. There was a high nitrate limitation during the wet months, however, stations in the sea (Lighthouse Beach 2, Great Wall of Lagos 1 and 2) and the harbour channel, with the exception of the creeks, experienced phosphate limitation in May and June, 2015. On the other hand, the dry months were seen to record spatial variations in nitrate-phosphate ratios. Figure 9 depicts the nutrient stoichiometry between nitrate and phosphate for the study sites. 


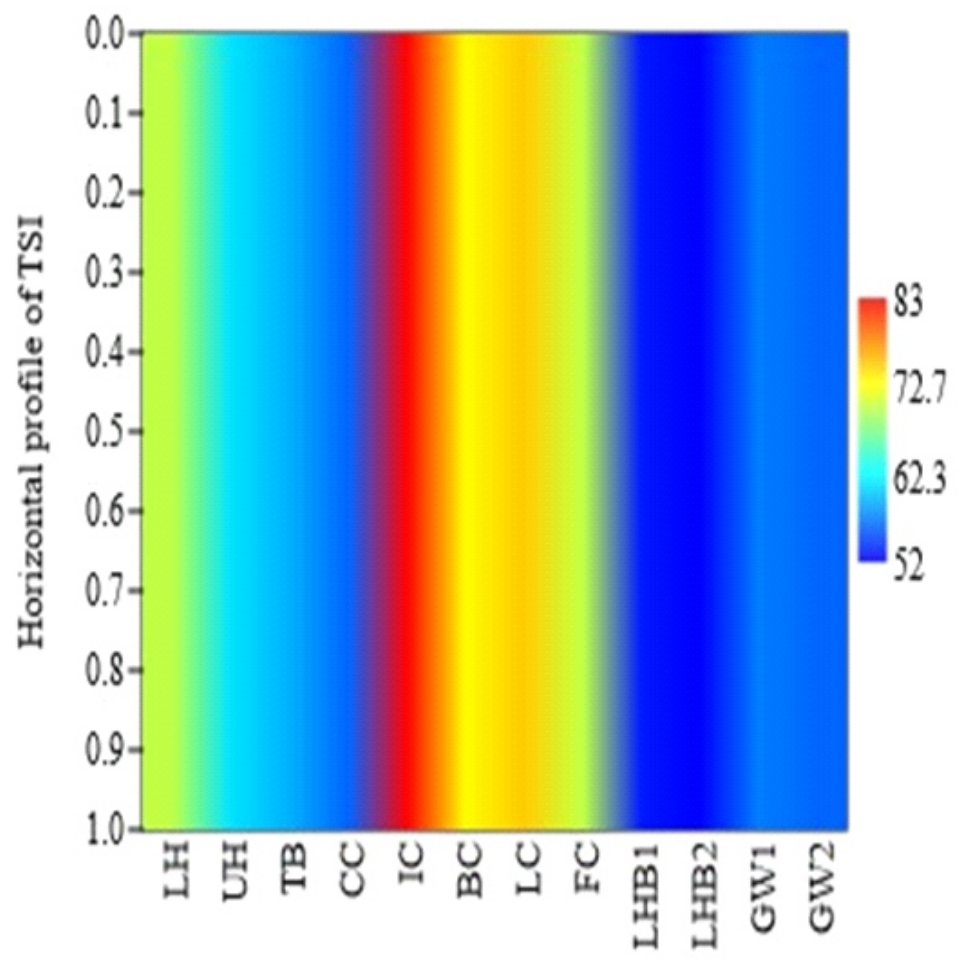

Figure 8: Profile of Trophic State Index, TSI along the Lagos Harbour and Adjacent Sea (January 2015 - June 2016)

$\mathrm{LH}=$ Lower Lagos Harbour, $\mathrm{UH}=$ Upper Lagos Harbour, $\mathrm{TB}=$ Takwa Bay, $\mathrm{CC}=$ Commodore Channel, IC= Ijora Creek, $\mathrm{BC}=$ Badagry Creek, LC $=$ Lighthouse Creek, FC $=$ Five Cowrie Creek, LHB1 = Lighthouse Beach 1, LHB2= Lighthouse Beach 2, GW1 = Great Wall of Lagos 1, GW2=Great Wall of Lagos 2

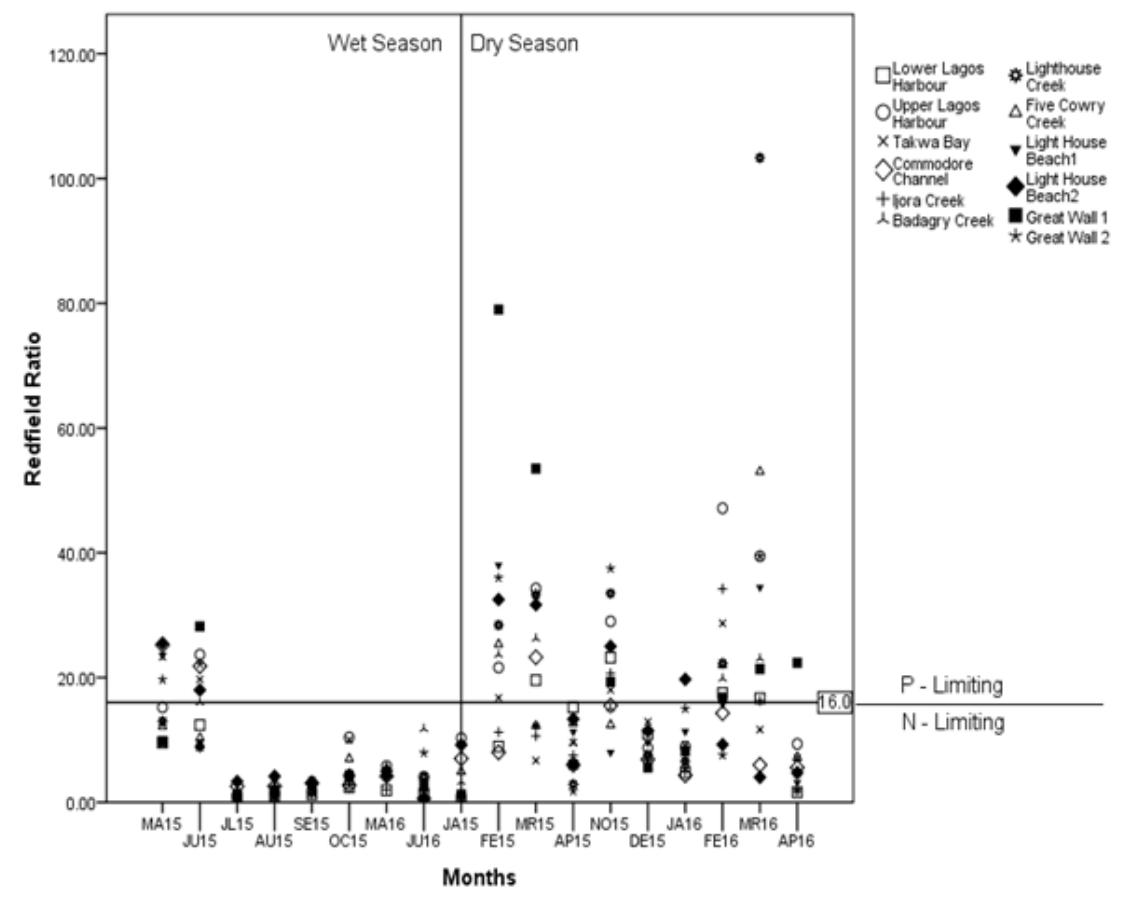

Figure 9: Nutrient Stoichiometry of Surface Water in the Sea Adjacent to Lagos Harbour (January 2015-June 2016)

NB: LH=Lower Lagos Harbour, IC=Ijora creek, BC=Badagry creek, LHC=Lighthouse creek, FC=Five-cowry creek; $\mathrm{JA}=$ January, $\mathrm{FE}=$ February, $\mathrm{MR}=$ March, $\mathrm{AP}=$ April, MA=May, JU=June, JL=July, AU=August, $\mathrm{SE}=$ September, OC=October, $\mathrm{NO}=$ November, $\mathrm{DE}=$ December, 15=Year 2015, 16=Year 2016 


\section{DISCUSSION}

Over the years, ecological studies have shown that phytoplankton community structure respond to fluctuations in water quality parameters (Nwankwo, 2004a; Reynolds, 2006; Opute and Kadiri, 2013). The physicochemical parameters investigated in this study from January 2015 to June 2016 clearly indicated seasonal changes that were closely related to the distributive pattern of rainfall for the West African region, which in turn, determined phytoplankton composition and abundance in the Lagos Harbour and adjacent sea.

According to Brown and Kusemiju (2002), rainfall pattern in the tropics is responsible for the dry (November - April) and wet (May - October) seasons experienced in West Africa. Rainfall is also known to be the major controlling factor for the distribution of terrestrial and aquatic organisms in the tropics. The Principal Component Analysis from this study, reaffirmed the significant role that is played by rainfall in this region. The salinity regime of the study sites, during this investigation, ranged from low brackish to marine conditions $(5.2-32.3 \%$ ) . According to Onyema (2008), there is an existence of environmental gradient determined by salinity in the Lagos lagoon and adjoining tidal creeks. The low brackish water conditions recorded during the wet season and high brackish conditions recorded in the dry season may be attributed to environmental gradients typical of transitional zones.

Higher values of total suspended solids were recorded in the wet months. This observation is attributable to high levels of organic matters brought into the harbour by run-offs from adjoining wetlands. Total Dissolved Solids (TDS) levels in stations which are in closer proximity to the construction site of the Eko Atlantic city, were significantly higher than those reported for the stations with lesser proximity to this city in both dry and wet seasons. This could be attributed to the aftermath effects of massive sand-filling which took place for the ongoing construction of this city. This influence was reflected in the composition of phytoplankton species which was dominated by pennate diatoms such as Achnanthes brevipes, Achnanthes longipes, Cocconeis diaphana, Cocconeis littoralis,
Cocconeis placentula and Tryblionella coarctata. These species are known to tolerate higher dissolved solids concentrations (Graham et al., 2009). The significant difference shown by phosphate in the wet season could be linked to resuspension of sediments, which are known to be a haven for phosphate in aquatic ecosystems. A pointer to this was the observed highest value of total suspended value recorded in June 2015, which coincided with the peak of rainfall in the same month of that year.

The significant effects of phosphate in the wet months, which was reflected on the abundance of cyanobacteria species and the eventual bloom of Oscillatoria tenuis in July, August and September 2015 was noteworthy. This bloom was largely associated with the creeks adjoining the Lagos Harbour as revealed by the Canonical Correspondence Analysis. This could be attributed to sediment re-suspension as a result of dredging and sand-mining activities in the lagoon system. The relative dominance of diatoms (Bacillariophyceae) in terms of abundance and diversity in all stations and across seasons reported, in this study is in agreement with earlier works done in the Lagos lagoon system (Nwankwo, 2004a; Onyema, 2007; Balogun and Ladigbolu, 2010; Nwankwo et al., 2012). Diatoms, which are known to be good indicators of coastal ecosystems (Julius et al., 2006; Graham et al., 2009), were found to be dominated by tychoplanktonic forms which can tolerate varying degrees of salinity and dissolved solids unlike the typical purely marine planktonic species that were reported for the Lagos harbor by Hendey (1958). From this observation, it could be inferred that habitat modification has altered phytoplankton composition in the Lagos Harbour and the adjoining water bodies.

Trophic status analyses using Carlson's Trophic State Index (TSI) showed eutrophic to hypereutrophic conditions. The hyper-eutrophic conditions observed at stations in close proximity to the lagoonal water could be as a result of the introductions of allochthonous inputs and human-induced autochthonous eutrophication. In eutrophic waters, blue-green algae are known to be prevalent (Graham et al., 2009; Opute and 
Kadiri, 2013). On the other hand, frequent noxious algal blooms are features of hypereutrophic conditions (Carlson, 1977; Edmundson and Carlson, 1998). The numerical counts of bluegreen algae from the present study are in agreement with the trophic assessments of eutrophic and hyper-eutrophic waters. The stoichiometric nutrient limitation which revealed a clear nitrate limitation in the wet months could be attributed to rapid utilization of reactive nitrogen and an excessive phosphorus supply which could have resulted from the effects of dredging and sand-mining activities following a heavy rainfall recorded in June 2015. In the dry months however, there were fluctuations in the ambient nutrient stoichiometry between nitrate and phosphate. These observations could be linked to varying degrees of environmental and humaninduced stress on sampled stations.

Contrary to earlier reports that nitrate is the limiting nutrient in coastal waters of Nigeria (Nwankwo, 2004a), the present study revealed that seasonal and spatial patterns, as well as human activities are major factors influencing which nutrient will be limiting at any point in time.

\section{REFERENCES}

Al-kandari, M., Al-Yamani, F.Y. and Al-Rifaie, K. 2009. Marine phytoplankton Atlas of Kuwait's waters. Kuwait Institute for Scientific Research. 351pp.

Alvarez-Blanco, I. and Blanco, S. 2014. Benthic diatoms from Mediterranean coasts. Bibliotheca Diatomolica Volume 60. G e b r u d e r B o n t a e g e r Verlagsbuchhandlung Publisher. 405 pp.

American Public Health Association 2005. Standard Methods for the Examination of Water and Wastewater. $21^{\text {st }}$ ed. APHA New York. 1270pp.

Balogun, K. J. and Ladigbolu, I. A. 2010. Nutrients and phytoplankton production dynamics of a tropical harbor in relation to water quality indices. Journal of American Research, 6(9): 261-275.

Barbosa, A.B., Domingues, R.B. and Galvão, H.M. 2010. Environmental forcing of phytoplankton in a meditteranean estuary (Guadiana estuary, Southwestern Iberia): a decadal study of anthropogenic and climatic influences. Estuaries and Coasts, 33(2): $324-341$.

Brown, C.A. and Kusemiju, K. 2002. The abundance and distribution of Capitella capitata Fabricus in the western part of the Lagos lagoon, Nigeria. Journal of Scientific Research and Development, 7: $69-76$.

Carlson, R.E. (1977). A trophic state index for lakes. Limnological Oceanography, 22: $361-369$.

Castro, P. and Huber, M.E. 2005. Marine Biology ( $5^{\text {th }}$ ed.). McGraw Hill Publisher, New York. 452pp.

Chukwu, L.O. 2011. Ecophysiology of marine life: A Science or Management Tool? Inaugural Lecture Series, University of Lagos Press. 62pp.

Edmundson, J. and Carlson, S. 1998. Lake typology influences on the phosphoruschlorophyll relationship in subarctic, Alaskan Lakes. Lake and Reservoir Management, 14(4): 440 - 450.

Edokpayi, C.A. 2017. The beautiful creatures of the aquatic sediment: The Benthos, A divine gift to mankind. Inaugural Lecture Series, University of Lagos Press. 78pp.

Falkowski, P.G., Fenchel, T. and Delong, E.F. 2008. The microbial engines that drive Earth's biogeochemical cycles. Science 320, 1034-1039.

Graham, L.E., Graham, J.M. and Wilcox, L.W. 2009. Algae ( $2^{\text {nd }}$ ed.). Pearson Benjamin Cummings, USA. 616pp.

Hammer, O., Harper, D.A.T. and Ryan, P.D. 2001. PAST: Paleontological Statistic software package for education and data analysis. Paleontologia Electronica, 4(1): $1-9$. http://paleo-electronica.org/ 2001_1/past/issue1_01.htm. Accessed $10 / 07 / 2016$.

Hendey, N.I. 1958. Marine diatoms from some West African ports. Journal of Royal Microscopic Society, 77:28-88.

Julius, M.L., Curtin, M. and Tanaka, H. 2006. Stephanodiscus kusuensis, sp. nov a new Pleistocene diatom from Southern Japan. Phycological Research, 54:294-301.

Julius, M.L. and Theriot, E.C. 2010. The diatoms: 
a primer. In: The Diatoms: Applications for the Environmental and Earth Science ( $2^{\text {nd }}$ edition), J.P. Smol and E.F. Stoermer (editors). Cambridge University Press. pp. $8-20$.

Nwankwo, D.I. 2004a. The microalgae: our indispensable allies in aquatic monitoring and biodiversity sustainability. Inaugural Lecture Series, University of Lagos Press. 44pp.

Nwankwo, D.I. 2004b. A Practical Guide to the Study of Algae. JAS Publishers, Lagos. Nigeria. 84pp.

Nwankwo, D.I., Okedoyin, J.A. and Adesalu, T.A. 2012. Primary productivity in tidal creeks of south-west Nigeria II. Comparative study of nutrients and chlorophyll a variations in two Lagos Harbour creeks. World Journal of Biological Research, 5(1): $41-48$.

Onyema, I.C. 2007. The phytoplankton composition, abundance and temporal variation of a polluted estuarine creek in Lagos, Nigeria. Turkish Journal of Fisheries and Aquatic Sciences, 7: 89-96.

Onyema, I.C. 2008. A checklist of phytoplankton species of the Iyagbe lagoon, Lagos. Journal of Fisheries and Aquatic Sciences, 3(3): $167-175$.

Onyema, I.C. 2009. Pollution and the Ecology of Coastal Waters of Nigeria. Dolps and Bolps Investments Ltd., Lagos, Nigeria. 216pp.

Opute, F.I. and Kadiri, M.O. 2013. Phytoplankton Algae of Nigeria. I. The Desmids. Mindex Publishing Limited, Benin City, Nigeria. 304pp.

Perry, R. 2003. A guide to marine plankton of Southern California ( ${ }^{\text {rd }}$ edition). UCLA OceanGlobe. 23pp.

Reynolds, C.S. 2006. Ecology of Phytoplankton. Cambridge Press. 551pp. 
Appendix 1: Checklist of Phytoplankton Taxa in the Lagos Harbour and Adjacent Sea (January 2015 - June 2016)

\begin{tabular}{|c|c|c|c|c|c|}
\hline & Class 1: Bacillariophyceae & & & & \\
\hline 1 & Achnanthes brevipes C. Agardh & 48 & Mastogloia binotata Grunow & 5 & Nostoc sp. \\
\hline 2 & Achnanthes eureka Alvarez-Blanco \& Blanco & 49 & Mastogloia cuneata Meister & 6 & $\begin{array}{l}\text { Oscillatoria curviceps C. Agardh ex } \\
\text { Gomont }\end{array}$ \\
\hline 3 & Achnanthes longipes C. Agardh & 50 & Mastogloia emarginata W. Smith & 7 & Oscillatoria limosa C. Agardh \\
\hline 4 & Achnanthidium exiguum Grunow & 51 & Mastogloia sp. & 8 & Oscillatoria magaritifera Kutzing \\
\hline 5 & Actinocyclus subtilis W. Gregory & 52 & Melosira moniliformes O. F. Muller & 9 & Oscillatoria sp. \\
\hline 6 & Actinoptychus splendens Shadbolt & 53 & Melosira mummuloides Ehrenberg & 10 & $\begin{array}{l}\text { Oscillatoria tenius C. Agardh ex } \\
\text { Gomont }\end{array}$ \\
\hline 7 & Amphora hyalina Kutzing & 54 & Navicula cryptocephala Kutzing & 11 & Oscillatoria trichodes \\
\hline 8 & Amphora ovalis & 55 & Navicula expansa Hagelstein & & \\
\hline 9 & Asterionella japonica Cleve & 56 & Navicula formenterae Cleve & & Class 4: Dictyochophyceae \\
\hline 10 & $\begin{array}{l}\text { Aulacoseira granulata var angutissima } \\
\text { Ehrenberg (Plate } 5 \text { ) }\end{array}$ & 57 & Navicula mutica Kutzing & 1 & Dictyocha fibula Ehrenberg \\
\hline 11 & Aulacoseira sp. & 58 & Navicula rbyncocephala Kutzing & & \\
\hline 12 & Bacillaria paxillifer O. F. Muller & 59 & Navicula sp. & & Class 5: Dinophyceae \\
\hline 13 & Bacteriastrum delicatulum Cleve & 60 & Nitzschia linearis W. Smith & 1 & Ceratium bicephalum \\
\hline 14 & Biddulphia aurita Lyngbye & 61 & Nitzschia longissima Brebisson & 2 & Ceratium furca Ehrenberg \\
\hline 15 & Biddulphia obtusa Kutzing & 62 & Nitzschia palea Kutzing & 3 & Ceratium fusus Ehrenberg \\
\hline 16 & Biddulphia sinensis Greville & 63 & Nitzschia sigma Kutzing & 4 & Ceratium macroceros Ehrenberg \\
\hline 17 & Caloneis sp. & 64 & Odontella sp. & 5 & Ceratium sp. \\
\hline 18 & Chaetoceros atlanticum Cleve & 65 & Palmerina hardmaniana Greville & 6 & Ceratium trichoceros Ehrenberg \\
\hline 19 & Chaetoceros convolutus Castracane & 66 & Parlibellus delognei Van Heurck & 7 & Ceratium tripos O. F. Muller \\
\hline 20 & Chaetoceros decipens Cleve & 67 & Pinnularia major Kutzing & 8 & Dinophysix sp. \\
\hline 21 & Chaetoceros radicans $\mathrm{F}$. Schutt & 68 & Plagiogramma sp. & 9 & Gymnodinium sp. \\
\hline 22 & Cocconeis diaphana W. Smith (Plate 6) & 69 & Pleurosigma angulatum J. T. Quekett & 10 & Prorocentrium sp. \\
\hline 23 & Cocconeis littoralis R. Subrahmanyan & 70 & Pleurosigma sp. & & \\
\hline 24 & Cocconeis placentula Ehrenberg & 71 & Podosira montagnei Kutzing & & \\
\hline 25 & Coscinodiscus centralis Ehrenberg & 72 & Pseudonitzschia sp. & & \\
\hline 26 & Coscinodiscus excentricus Ehrenberg & 73 & Rhizosolenia styliformes $\mathrm{T}$. Brightwell & & \\
\hline 27 & Coscinodiscus jonesianus Greville & 74 & Stephanodiscus sp. & & \\
\hline 28 & Coscinodiscus lineatus Ehrenberg & 75 & Surirella recedens & & \\
\hline 29 & Coscinodiscus radiatus Ehrenberg & 76 & Synedra crystallina C. Agardh & & \\
\hline 30 & Cyclotella caspia Grunow & 77 & Synedra sp. & & \\
\hline 31 & Cyclotella meneghiniana Kutzing (Plate 4) & 78 & Synedra ulna Nitzsch & & \\
\hline 32 & Cyclotella stylorum Brightwell & 79 & Terpsinoe muscica Ehrenberg & & \\
\hline 33 & Diploneis sp. & 80 & Thalasiothrix sp. & & \\
\hline 34 & Ditylum brightwelli Grunow & 81 & $\begin{array}{l}\text { Thalassionema longissima Cleve \& } \\
\text { Grunnow }\end{array}$ & & \\
\hline 35 & Endictya oceanica Ehrenberg & 82 & Thalassiosira sp. & & \\
\hline 36 & Eunotogramma marinum W. Smith & 83 & Trachyneis sp. & & \\
\hline 37 & Fragilaria construens Ehrenberg & 84 & Tryblionella coarctata Grunow & & \\
\hline 38 & Fragilaria sp. & & & & \\
\hline 39 & Gomphonema sp. & & Class 2: Chlorophyceae & & \\
\hline 40 & Grammatophora marinum Lyngbye & 1 & Gonatozygon monoteanium & & \\
\hline 41 & Guinardia flaccida Castracane & 2 & Spirogyra africanus F. E. Fritsch & & \\
\hline 42 & Gyrosigma sp. & & & & \\
\hline 43 & Halamphora sp. & & Class 3: Cyanophyceae & & \\
\hline 44 & Hemidiscus cuneiforms Wallich & 1 & Anabaena spiroides Klebhan & & \\
\hline 45 & Hyalosynedra laevigata Grunow & 2 & $\begin{array}{l}\text { Lyngbya martensiana Meneghini ex } \\
\text { Gomont }\end{array}$ & & \\
\hline 46 & Licmophora lyngbyei Kutzing & 3 & Microcystis aeruginosa Kutzing & & \\
\hline 47 & Licmorpha abbreviata C. Agardh & 4 & Microcystis flos-aque Wittrock & & \\
\hline
\end{tabular}

Appendix 2: Monthly Rainfall values ( $\mathrm{mm}$ ) in Lagos State, Southwest, Nigeria, for the sampling period (January, 2015 - June, 2016)

\begin{tabular}{|c|c|c|c|c|c|c|c|c|c|c|c|c|c|c|c|c|c|}
\hline \multicolumn{12}{|c|}{2015} & \multicolumn{6}{|c|}{2016} \\
\hline Jan. & Feb. & Mar. & April & May & June & July & Aug. & Sept. & Oct. & Nov. & Dec. & Jan. & Feb. & Mar. & April & May & June \\
\hline 0.1 & 28.2 & 33.8 & 74.1 & 216.1 & 449.3 & 207.1 & 45.9 & 96.6 & 200.4 & 48.7 & 4.1 & 25.6 & 5.4 & 164.4 & 84 & 167.3 & 331.8 \\
\hline
\end{tabular}

